University for Business and Technology in Kosovo

UBT Knowledge Center

Oct 28th, 4:00 PM - 5:30 PM

\title{
Aspects of Translation Theory, and Comparison to translation English-Albanian from the author G. R. Berridge, Diplomacy Theory and Practice and Albanian version G. R. Berridge Teoria dhe Praktika
}

Redi Papa

University for Business and Technology, redi.papa@ubt-uni.net

Halil Bashota

University for Business and Technology, halil.bashota@ubt-uni.net

Follow this and additional works at: https://knowledgecenter.ubt-uni.net/conference

Part of the Education Commons

\section{Recommended Citation}

Papa, Redi and Bashota, Halil, "Aspects of Translation Theory, and Comparison to translation EnglishAlbanian from the author G. R. Berridge, Diplomacy Theory and Practice and Albanian version G. R. Berridge Teoria dhe Praktika" (2017). UBT International Conference. 120. https://knowledgecenter.ubt-uni.net/conference/2017/all-events/120

This Event is brought to you for free and open access by the Publication and Journals at UBT Knowledge Center. It has been accepted for inclusion in UBT International Conference by an authorized administrator of UBT Knowledge Center. For more information, please contact knowledge.center@ubt-uni.net. 


\title{
Aspects of Translation Theory, and Comparison to translation English-Albanian from the author G. R. Berridge, Diplomacy Theory and Practice and Albanian version G. R. Berridge Teoria dhe Praktika
}

\author{
Redi Papa, Halil Bashota \\ UBT-Higher Education Institution, Lagjja Kalabria, 10000 n.n., \\ Pristina, Kosovo \\ \{halil.bashota, redi.papa\}@ubt-uni.net
}

\begin{abstract}
The main aim of this topic is to provide a full-fledged analysis of the terminology used in the diplomatic field and to achieve this an in-depth analysis of two chapters from two books is elaborated, one is in Albanian Language and the other in English Language. The author of the book is the renowned scholar of diplomacy G. R. Berridge, Diplomacy Theory and Practice and the version in Albanian "Diplomacia, Teoria dhe Praktika". To achieve a comparison of translation between the Albanian and English version it was necessary to carefully scrutinize and carry out a detailed analysis of translation aspects such as the Importance of Equivalence, Methods of Analysis, Grammatical Structure, Synchronic Approach and Diachronic Approach to the text and to draw the difference between the Political and Administrative Style. In addition to this it was of significant importance to make an ample lexical analysis of the key words and expressions. The misinterpretations of certain words in the diplomatic terminology may aggravate and take the shape of a conflict. So, contribution in this aspect of translation appears to be essential and in relevance to contemporary problematic.
\end{abstract}

Keywords: Importance of Equivalence, Methods of Analysis, Grammatical Structure, Synchronic Approach, Diachronic Approach.

\section{Introduction}

First and foremost it is worth mentioning that translation a very broad discipline in itself, that give's the nations the opportunity to cooperate between each other through an interactive communication. Translation as an important part of communication is worthy and gives a great contribution as in the process of cross-cultural communication and anticipates and mediates the worldwide political developments. Above all, translation is an art, and being so it is true in it significance.

The main purpose of this paper is to provide a full-fledged and a comprehensive analysis of the underlying aspects of translation. To illustrate this, I have carried out a comparison to translation between two pieces one in Albanian version and the translated version in English. Indeed to enable this it was indispensable to make an in-depth analysis of such elements such as a comparison in the grammatical level, the style of translation, methods of analysis, the key words and the most distinctive expressions of the text which an integral part of the lexical analysis. Due to the fact that the book I have chosen to analyze, it is comprised of an enriched diplomatic terminology, it was of great importance to browse and find out the respective synonyms of the most distinctive word units.

In the course of global developments, diplomacy is playing a crucial role in appeasing and conflicts which source out mainly as a consequence of inadequate communication. In this 
perspective the role of translation is of significant importance. Needless to say, it is impossible to perceive and convey messages in global level without a proper and faithful translation. Translation is a complicated and intricate process in itself and a very demanding task. A translation may be faithful, word-for-word translation and literal one. According to my approach, the translator has remained faithful to the author and in order to explicitly convey his ideas and to be lucid and straightforward.

\section{Theoretical Analysis to translation}

It is generally agreed so far that meaning is very important in translation (Catford, 1965: 35). Indeed translation has often been defined with relevance to the meaning. According to this approach, a translation ought to have the same meaning with the original, but should not sound like a translation. As far as this issue is concerned, I will provide my own illustrations about between English and Albanian versions and respectively to point out which is distinguished as a translated text and which not. The case of meaning is in fact conventionally packaged in the languages, either source or target language. What's important to be mentioned is that each language has its distinctive forms and traits, and as matter of fact translators have to perceive and realize that not all elements of a language are have their equivalents in the other language. Therefore finding the equivalence may be considered one of the main obstacles which are commonly faced by the translators.

Baker (1992) mentions that there are five levels of equivalence namely a) equivalence at word level, 2) equivalence above the word level 3) grammatical equivalence 4) textual equivalence 5) pragmatic equivalence. The process of analyzing all this levels analysis is quite complex, but the most intricate level of equivalence appears to be that of grammatical equivalence. There are a variety of grammar categories that may not be expressed in different languages. Baker mentions five levels of equivalence that lead to difficulties in finding the equivalence during the process of translation, there are : Number, Gender, Person, (the system of pronoun), Tense and Voice. This particular issue focuses on three of those grammatical categories, namely the category of Person, Tense and Voice.

\section{Grammatical equivalence in Translation}

There are various definitions related to this term. In Merriam Webster Dictionary (1989), to translate means to change one text from one state to another, or to turn one text into ones other language. Translation may be defined as a product as well as a process. The following is the definition of the word "translation", in Concise Oxford Dictionary, are such as follows:

1.) The process of transferring a written text from SL to TL, conducted by a translator, or translators in specific socio-cultural context.

2.) The written product or TT, which results from that process and which functions in the socio-cultural context of the TL.

3.) The cognitive, linguistic, visual, cultural and ideological phenomena which are an integral part of part 1 and 2.

Mona Baker states that translation is conceived primarily as a process of intercultural communication, whose definite product is a text, which is capable of functioning appropriately in specific situations and contexts of use. What makes translation complicated is the diversity or 
the lack of one-to-one correlation between form and meaning, considering the fact that each language has its own distinctive forms for representing the meaning.

Newmark (1988:32), therefore mentions that translation is the super-ordinate term for converting the meaning of any utterance from the source language to the target language. To achieve this translator needs to consider the content of the text rather than the form. Newmark emphasizes that the objective of translation is to replace the form and preserve the content of a given text. Therefore in translation the same meaning may have to be expressed in another language in a very different form. This means that the meaning must have priority instead of form. Baker (1992) has made a classification on the notion of the equivalence in translation. He states that grammar is set of rules which determine the way which units such as words and phrases can be combined in a language and the kind of information which has to be made in regularly explicit in utterances. Baker also states that the differences in grammatical structures of the source and target language may result in some change of information, concerning the content of the message during the translation process.

\section{Translation and Style}

The style of diplomatic texts is closely connected to the style of social and political activity. The sphere of this style is comprised of the social and political activity. The sphere of this style is comprised of socio-political publications such as books, congresses, proclamations, meetings. According to the communication facilities, there are distinguished other vast and vide divisions that compose the so called sub-styles which concern writing, public oral forms, press propaganda and so on.

Public oral forms imply three basic types of speeches, debates and political rhetoric Lloshi (2005). Oratory has been the genesis of the elaboration style. It has been of significant importance and has represented intellectual activity of its respective population. Taking the word in front of the audience requires utmost proficiency of the oral linguistic skills and an overall notable cultural background. In order to achieve the solemn tone there must be particularly unfolded the syntax derivations such as (parallelisms, repetitions, rhetoric questioning and reticence's). Diplomacy is a complex and intricate discipline and as a result is directly influenced by oratory. Oratory is one of indivisible components.

The tone of the text, the tone of this text is an emotional, polemical, and a striking one. Nevertheless, it is worth mentioning that the individual tone is counter posed and afflicted in its essence by social stances and estimations.

According to Lloshi (2005), the stylistic function of socio-political and diplomatic discourse is influential and proclaiming one. In this framework proclamation implies a scientific scrutiny of data, facts events from various fields such as culture, economy, politics that concern diplomacy and political studies. Meanwhile the influential function of this style presupposes not only the influence over thoughts, and evaluations of readers and listeners, but it aims at fostering social controversies. Generally speaking the social functions of this activity are mainly; informative, organizational, cognitive and educative. These are the basic elements by which this stylistic function is approached.

The text formation. The text peculiarities are derived from the foremost principle of stylistic arrangement and from employing the standard language in texts.

The lexical richness of diplomatic terminology in the book

The language of this text is obviously a complex and intricate language. The text is chiefly composed of a standard language which an enriched lexis. Comparing the texts both in English and Albanian, I have witnessed different ways of conveying the message. 


\section{Methods of Analysis in Translation}

It's worth mentioning that amidst many other methods of analysis experimented during the different pieces only three of them are apparently more applicable. Beside other methods, respectively the method of functional analysis, which strives to scrutinize the role and style concerning the whole structure of a particular literary work, this is enabled through the psychological and literary methods of analysis and from the statistical method as well, Ristani (2010). A subtle and in-depth analysis of these is utterly demanding, and is unavoidable to leave apart the method of key words which is interwoven in its entirety with these three methods of analysis and is probably a key method of linguistic analysis. I have briefly elaborated only two of them.

Functional Method

As far as the functional approach is concerned, the stylistic is defined as a linguistic element for literary purposes in a given literary work. The style does not appear as a psychological document but as one of the most necessary and essential documents of a literary work. Consequently, to the main issues of the stylistic analysis as matter of fact ought to be in the size of an optimal context. Context in the stylistic studies is clearly and fully treated through the presence and the distinctive features between the micro-context and the direct straightforward context that shapes the entirety of stylistically unmarked components. On the contrary, macro-context implies a broad context, specifically that part of message that anticipates the stylistic utterances. If we choose the microcontext to analyze prose and poetry, we are obliged to go through an inept and limited analysis, which enables just a mere scrutiny of the way how stylistic devices interact and influence each other, Ristani (2010). Nevertheless, as it is mentioned above only the ability to point out the most remarkable stylistic traits and to penetrate in the structure of the text to determine the basic pillars how to develop the structure, can lead to precise conclusions.

The psychological Method

One of the most remarkable form of these methods of analysis is as well that of close reading, explication de texte, or even the Spitzerian circuit, which beside improvements and elaborations, shares common intentions and incorporate historical, cultural, esthetical information with the branch of linguistics. Leo Spitzer in his youth was utterly influenced by Sigmund Freud, without forgetting to mention in this context Vossler and Croce who focused their papers in further elaboration of stylistic features through intuition, the integral parts of the Spitzer's circuit were these three stages:

- In the first stage the scholar or the critic rereads with patience and self-esteem concerning only its outer appearance, observing the details and integral components of the literary work, until he distinguished a repetition of stylistic traits.

- In the second stage, after having categorized the details, and trying to incorporate them together in a creative principle that might have originated from the authors psyche, tries to explain these features from the psychological approach.

- In the third stage the scholar strives to find out further data, referring to the same factor of the authors psyche. In this way Spitzer established an organic relation through style, the psyche of the author and other features related to him.

\section{Theories of Equivalence}

Jacobson's Equivalence Theories: R.Jakobson (1959), believes that equivalence comes in three types; inter-semiotic equivalence, (equivalence between sign systems), inter-lingual (equivalence between two languages), and intra-lingual, (equivalence within one language; paraphrasing or 
rewriting the same content). The second type, intra-lingual, is one where translation equivalence is classified in.

Nida Equivalence Theories: Conversely, E.A Nida (1964), has written that there are two kinds of equivalence; a) formal equivalence (also known as formal correspondence), and dynamic equivalence. Formal equivalence is more concerned with word-for-word translation and content faithfulness, while dynamic equivalence is focused upon context and sense-for-sense adaption.

The bottom line here is that all translation theories are somehow connected with the notion of equivalence in one way or another. Consequently, equivalence is an important philosophy when it comes to translation theory and its many different practical applications. Actually, both target and source language include equivalent ranges from the least significant morphemes to the most meaningful levels (sentences).

These levels of language are the ones that keep the ones that help strike the proper balance between two much faithfulness to the original text and too much pandering to the target audience. Accordingly, translation is all about creating a balance between the original language document and the target language document.

\section{Comparison to Translation between Two Paragraph's English- Albanian}

A practical illustration of equivalence is great importance, and to carry this out I've reasoned it out as worthy to make a comparison to translation between two paragraphs such as follows:

\section{English Version}

Though it is common to assume that multilateral diplomacy is essentially a twentieth century phenomena, its origins in fact lie much earlier. It was important in diplomacy between allies in ancient India and even beyond allies in the Greco-Persian world, in the fourth century BC. Within the European system states, somehow chaotic multilateral conferences devoted to peace settlements (referred to as 'congresses', when of special importance), were the future of seventeenth century. Nevertheless, multilateral diplomacy did not begin to take modern form until the early nineteenth century following the end of Napoleonic Wars. Since the global system, the immediate origins of modern multilateral diplomacy are found here. When, then, did it emerge most emphatically in the nineteenth century blossom in the twentieth century? Berridge (2002)

\footnotetext{
Albanian Version

Megjithëse zakonisht diplomacia shumëpalëshe ështe kryesisht dukuri e shekullit të njëzetë, origjina e saj në fakt shkon më pas në histori. Ajo ka qënë e rëndësishme për diplomacinë midis aleatëve të Indisë së lashtë por edhe në diplomacy shërbente si bazë e aleancave të botës grekopersiane të shekullit të katërt pas Krishtit. Edhe në sistemin Europian të shteteve për të përgatitur dhe përfunduar marrëveshje paqe, u organizuan nje numer konferencash disi kaotike, kur qenë me rëndësi të vecantë të emërtoheshin "kongrese". Këto ishin tipar pothuajse i zakonshem i shekullit të shtatëmbëdhjetë. Sidoqoftë, diplomacia shumëpalëshe nuk arriti të marrë formë moderne deri në shekullin e njëzetë, me përfundimin e luftërave të Napoleonit. Meqënëse sistemi global i shteteve rrjed direkt nga modeli evropian, dhe rrënjët e diplomacisë europiane duhen kërkuar aty. Përse fillimisht lindi në shekullin e nëntëmbëdhjetë, por lulëzimin e plotë e gëzoi në të njëzetin?
} 
Analysis of the grammatical and lexical aspects of the most notable keywords Qesku (2004).

Peace settlement: renders the equivalent i Albanian is marrëveshje paqeje

Emphasize: verb, renders the meaning in Albanian, theksoj

Ally : noun renders the equivalent in Albanian aleat.

Emerge: verb renders the equivalent in Albanian : dal, ngrihem.

Emphatic : adjective, renders the equivalent in Albanian: emfatik i theksuar.

Emphatically : adverb, renders the equivalent in Albanian : me force, dukshëm me theksim të vecantë

English-English Explanation (Oxford Advanced Learners Dictionary).

Emphasize, verb, it derives this meanings: to give a special importance to something important, worthy and useful.

Emphatic, adjective, derives this meanings; a strong forceful way to show that it is important. Example "An emphatic denial".

Emphatically, adverb; is used to state a proclamation in emphatic manner, Example:"It was emphatically denied".

Emerge : verb, derives the meanings; to come out of the dark, to start to exist, to appear or become known, and other meanings are; to survive in a difficult situation.

\section{Synchronic Approach and Diachronic Approach of the text}

A synchronic approach analyzes something given in a fixed point in the past. In the framework of a diplomatic perspective, it provides a panorama of diplomacy that has taken place in a certain period in the past. Consequently, it does not make any deductions about the events that have contributed to the current state, but only observes the structure of every discipline.

\section{Diachronic Approach of the text}

The Diachronic Approach of Diplomacy provides an outlined scrutiny of the evolution of something over time, allowing one to access how this discipline has evolved in the course of historical developments. The in the course of historical developments. This approach enables a vast and wide scrutiny of the effects of variable changes on every discipline. This discipline originates from ancient period, diplomacy was enhanced in ancient Greece and especially from the political, military leaders in relations with foreign states.

\section{Conclusions}

- Translation is primarily conceived as an intercultural communication, and the final product is a text is capable of functioning appropriate situations and contexts of use.

- Translation may also be defined as the process of conveying the meaning of an utterance from source to target language

- Equivalence is one an integral part of the translation process, and it is divided in three categories; inter-semiotic (equivalence between signs and systems), inter-lingual (equivalence between languages) and intra-lingual equivalence (equivalence within one language, paraphrasing or rewriting the same content. 
- The style of diplomacy is closely connected with the style of social and political activity. The sphere of this style is comprised of socio-political publications such as (books, congresses, proclamations, meetings).

- The stylistic function of socio-political discourse is an influential and proclaiming one, which means it elaborates scientific data in various fields such as culture economy and diplomacy.

- The analysis of key words especially in the lexical and grammatical level comprises a necessity.

- During the last decade translation of diplomatic texts is gaining a significant importance. A faithful translation avoids the occurrence of disputes and even arm conflicts. A distortion of the meaning of a certain context may lead to severe disputes among nations.

\section{Bibliography}

1. Viktor Ristani, “Kontribut në Studimet Përkthimore Gjatë Viteve 90”, Mirgeealb, 2010.

2. Oxfords Advanced Learners Dictionary.

3. Pavli Qesku Fjalor “Anglisht-Shqip”, EDFA, 2004.

4. Xhevat Lloshi, "Stilistika dhe Pragmatika e Gjuhës Shqipe", Albas 2005.

5. Peter Newman, "A Textbook of Translation," New York Prentice Hall.

6. Nida E. "Towards a Science of Translating" Leiden E.J Brill, 1964.

7. Mona Baker, "In other words, A Course book of Translation", London Routledge.

8. Roman Jacobson "On Linguistic Aspects of Translation", essay, 1959.

9. G.R.Berridge, "Diplomacy Theory and Practice",Palgrave McMillan, 2002.

10. https://www.thoughtco.com/diachronic-linguistics-term-1690385

11. https://www.britannica.com/science/synchronic-linguistics

12. Webster Dictionary of English Usage, Springfield Massachusetts, 1989. 